\title{
Validation of a Football Competence Observation System (FOCOS), Linked to Procedural Tactical Knowledge
}

\author{
Rubén Sánchez-López *D, Ibon Echeazarra and Julen Castellano \\ Department of Physical Education and Sport, University of the Basque Country (UPV/EHU), \\ 01007 Vitoria-Gasteiz, Spain; ibon.etxeazarra@ehu.eus (I.E.); julen.castellano@ehu.eus (J.C.) \\ * Correspondence: ruben.football@gmail.com
}

Citation: Sánchez-López, R.;

Echeazarra, I.; Castellano, J.

Validation of a Football Competence Observation System (FOCOS), Linked to Procedural Tactical Knowledge. Sustainability 2021, 13, 6780. https:// doi.org/10.3390/su13126780

Academic Editor: Emilio Villa-González

Received: 3 May 2021

Accepted: 10 June 2021

Published: 15 June 2021

Publisher's Note: MDPI stays neutral with regard to jurisdictional claims in published maps and institutional affiliations.

Copyright: (c) 2021 by the authors. Licensee MDPI, Basel, Switzerland. This article is an open access article distributed under the terms and conditions of the Creative Commons Attribution (CC BY) license (https:/ / creativecommons.org/licenses/by/ $4.0 /)$.

\begin{abstract}
The use of instruments for the evaluation of a player's procedural tactical knowledge (PTK) in sociomotor sports, such as football, is a line of research of growing interest since it allows a pertinent description of the player's football competence. The aim of this study is to configure and validate an ad-hoc observational tool that allows evaluating the player's PTK, understood as football competence, from the observation, coding and recording of the roles, the actions of the acquired subroles and the operational and specific principles of football in the attack and defense phases. Based on the Delphi method, a field format coding instrument was designed and validated where each criterion is a system of categories, exhaustive and mutually exclusive. The results showed excellent content validity (9.02 out of 10$)$, and high values of intra-observer stability $(\mathrm{k}=0.747)$ and inter-observer agreement $(\mathrm{k}=0.665)$. Generalizability analysis showed an excellent reliability $(\mathrm{G}=0.99)$. Additionally, the construct validity of the tool was calculated through a small-sided game Gk $+4 \mathrm{v} 4+\mathrm{Gk}$, using two independent samples: semi-professional and amateur players. The results reflected significant differences $(\alpha<0.05)$ between both samples in the variables total score, offensive score and defensive score. Therefore, this study provides a valid and reliable instrument that allows data collection in a rigorous and pertinent way, as well as their analysis and evaluation in attack and defense according to the roles of the players and based on the motor behaviors that they perform using the subroles that they acquired, associated with the technical dimension, along with the principles that they develop in parallel, in support of the tactical dimension.
\end{abstract}

Keywords: technical-tactical performance; tactical behavior; game principles; roles; subroles; football; soccer; assessment; small-sided games

\section{Introduction}

The construction of instruments for the evaluation of the tactical knowledge of the players in sociomotor sports [1], as is the case of football, is a line of research of increasing interest due to the importance that tactic dimension assumes in training and performance [2]. In this sense, the instruments proposed for the tactical evaluation of the player have been developed and classified into two perspectives according to the type of tactical knowledge that has been evaluated. One perspective refers to declarative tactical knowledge (DTK), that is, "knowing what to do", through knowledge of the rules, positions, functions, offensive and defensive strategies, and understanding of the technical-tactical logic of the game [3]. The perspective of the procedural tactical knowledge (PTK) is intimately linked to the particular motor action [4-6], that is, "to know how to do". The latter, the tactical dimension of behavior, is decisive in a sport like football, with a very complex logic due to its high unpredictability and randomness of events [7], and refers to the player's performance in the context of the game [8] or to football competence [9].

To analyze and assess the behaviors of the players, several methods have been used, as can be observed in systematic reviews on match analysis carried out in soccer [10] and other team sports [11-14]. From the observational methodology [15], there is a wide variety 
of instruments to assess PTK in football, such as "Performance Assessment in Team Sports" (TSAP) [16], "Game Performance Assessment Instrument" (GPAI) [17], "Procedural Tactical Knowledge Test" (KORA) [18], validated by Memmert [19], "System of Tactical Assessment in Soccer" (FUT-SAT) [20], "Game Performance Evaluation Tool" (GPET) [21] and "Instrument for the Measurement of Learning and Performance in Football" (IMLPFoot) [22]. These tools are articulated around the tactical variables or game principles [23] that each author takes into consideration, resulting in very different configurations, and reflecting the difficulty that exists when evaluating the motor behaviors that are developed by the players in the collective games [24].

The most important limitations of these tools are as follows: focusing only on the attack phase (TSAP, KORA, GPET), or solely on the evaluation of the player with the ball (TSAP); not covering all the possibilities that the player has to respond in every situation (TSAP, KORA, GPAI, GPET, IMLPFoot); not using game principles to classify the behaviors carried out by the player (TSAP, GPAI, KORA, IMLPFoot); resorting to game principles, without analyzing the tactical behaviors that the player displays (FUT-SAT). It can be said that no tool offers a complete coding system around the roles and subroles of the football player, which allows the deployment and analysis of motor behavior based on these, leading to a relevant evaluation of the player's football competence.

Taking into account the limitations presented by the tools shown, it is interesting to note that the dual structure of sociomotor games leads to understand that the sociomotor roles that the participant can assume can be different when attacking and defending [25]. Taking as a reference the concept of "game center" [26], different roles can be identified depending on the relationship of closeness between ball and player [27]. However, this level of specification does not seem sufficient to allow a rigorous and detailed analysis of the game action, for which it is necessary to go to the subroles associated with each of the player's roles. Some studies $[28,29]$ have delved into the study of motor behaviors in football through the use of sociomotor subroles, allowing to appreciate, in the case of each player, the particular orientation they make of their role [30] and the consequent possibilities of action. The possibilities of action of the players can be framed within the game principles. The current literature includes various types of game principles: operational principles [31], fundamental principles [32,33] and specific principles [5,32-37], in addition to the principles associated with the game model to be transmitted, linked to a certain way of playing. They can all can facilitate the framing of tactical behaviors shown by teams and players, contributing to the design of instruments that reflect with greater specificity and superior relevance the events that happen in a match or training [38,39].

Given all of the above, the objective of this study is to configure and validate an observation tool designed ad-hoc to evaluate a player's PTK, understood as football competence, based on the observation, coding and recording of the roles, the own actions of acquired subroles and the principles adopted by the players in the game. To achieve this objective, guaranteeing the validity and reliability of the data collected is important so that the performance analysis can effectively fulfill its intentions and purposes [40]. For this, it seems necessary to determine the degree of validity and reliability of ad-hoc tools from various dimensions. This is, on the one hand, the content, construct and criterion validity [41], and on the other hand, the stability and agreement of the instrument, based on its intra-observer and inter-observer reliability. The results of the present study allow the applicability of the instrument not only in the scientific field, but also in the field of evaluation of pedagogy and sports training.

\section{Materials and Methods}

\subsection{Design}

The study responds to an observational design that is punctual, idiographic and multidimensional [42]. It is idiographic because it is focused on a study unit, the player in particular; it is punctual because the data collection is carried out in a single session, and not throughout a season; and it is multidimensional, because the effectiveness index of the 
tactical behaviors displayed by the player is studied based on various criteria. Therefore, for data collection, it is necessary to configure an ad-hoc instrument, which, conditioned by the structure of the observational design, will be a field format coding instrument where each criterion is a system of categories, exhaustive and mutually exclusive [43]. For all this, the data type is sequential and event-based, since the observer collects the order of events, not their duration, and only one behavior can take place at a time [44].

\subsection{Participants}

During the design and reconfiguration stages of the instrument that gave way to its validation, a total of 31 experts contributed their conclusions via "Google Forms" in three different phases ( $n=6, n=8, n=17)$. Experts had to meet at least two of the following three requirements: (1) have more than 10 years of experience training, (2) be graduates in physical activity and sports sciences with a specialty in football, (3) and be active coaches with a minimum qualification of professional level.

To establish the construct validity of FOCOS, two similar small-sided games (SSG) $\mathrm{Gk}+4 \mathrm{v} 4+\mathrm{Gk}$ were recorded and analyzed using two independent samples: eight semiprofessional players (21.68 \pm 1.38 years old), who were active in Spanish Second Division B playing in the reserve team of a "La Liga" club, and eight amateur players from a club of the last category of federated football in Madrid (25.30 \pm 2.15 years old). Goalkeepers were not considered in any of the samples. In addition, for the reliability process, two observers were trained in the use of the tool, joining the experimenter, who acted as the third observer.

\subsection{Coding Instrument}

The Football Competence Observation System, FOCOS, was developed taking as reference various studies around the classifications of operational [31] and specific principles $[5,32-37]$ as well as the roles [27] and subroles [28,29]. The new tool is formed by the combination of a field format and exhaustive and mutually exclusive category systems, based on six criteria (phase, role, own action of the subrole, operational principle, specific principle and result of the action) that appear in Table 1.

Table 1. Criteria and category systems of the Football Competence Observation System (FOCOS).

\begin{tabular}{|c|c|c|c|c|c|}
\hline Phase & Role & $\begin{array}{l}\text { Own Action of } \\
\text { the Sub-Role }\end{array}$ & $\begin{array}{c}\text { Operational } \\
\text { Principle }\end{array}$ & Specific Principle & $\begin{array}{l}\text { Result of the } \\
\text { Action }\end{array}$ \\
\hline Attack & $\begin{array}{l}\text { Attacker with the ball } \\
\text { Attacker without the } \\
\text { ball in the game center } \\
\text { Attacker without the ball } \\
\text { out of the game center }\end{array}$ & $\begin{array}{l}\text { Ball control } \\
\text { Driving } \\
\text { Dribble } \\
\text { Passing } \\
\text { Shooting } \\
\text { Move off-the-ball } \\
\text { Positioning }\end{array}$ & $\begin{array}{l}\text { Maintain ball } \\
\text { possession } \\
\text { Progress towards } \\
\text { rival area } \\
\text { Achieving the goal }\end{array}$ & $\begin{array}{l}\text { Penetration } \\
\text { Offensive coverage } \\
\text { Depth mobility } \\
\text { Width and length } \\
\text { Offensive unity }\end{array}$ & $\begin{array}{l}\text { Successful } \\
\text { Improvable Wrong }\end{array}$ \\
\hline Defense & $\begin{array}{l}\text { Defender in the } \\
\text { intervention space } \\
\text { Defender in game center } \\
\text { Defender out of game } \\
\text { center }\end{array}$ & $\begin{array}{l}\text { Tackling } \\
\text { Interception } \\
\text { Dissuading } \\
\text { Relocating }\end{array}$ & $\begin{array}{l}\text { Regain Possession } \\
\text { Prevent opponent's } \\
\text { progre ssion } \\
\text { Protect the goal }\end{array}$ & $\begin{array}{l}\text { Delay } \\
\text { Defensive coverage } \\
\text { Balance } \\
\text { Concentration } \\
\text { Defensive unity }\end{array}$ & $\begin{array}{l}\text { Successful } \\
\text { Improvable Wrong }\end{array}$ \\
\hline
\end{tabular}

Taking the observation system proposed, the observer analyzes the volume and effectiveness of the behaviors that the player is displaying based on the criteria described. For this, the observer must know in detail the definitions of the categories (see Table 2). Volume and effectiveness are two performance indicators that have also been used in TSAP [16]. 
Table 2. Codes and definitions of observation categories.

\begin{tabular}{|c|c|c|c|c|}
\hline Criterion & Category & Code & & Definition for Observation \\
\hline & Attack & AT & & team of the player to be analyzed has possession of the ball \\
\hline Phase & Defense & DF & & team of the player to be analyzed does not have possession of the ball \\
\hline \multirow{6}{*}{ Role } & $\begin{array}{l}\text { Attacker with the } \\
\text { ball }\end{array}$ & $\mathrm{Acb}$ & \multicolumn{2}{|r|}{ The player to be analyzed has possession of the ball } \\
\hline & $\begin{array}{l}\text { Attacker without the } \\
\text { ball in the game } \\
\text { center }\end{array}$ & Asb:c & \multicolumn{2}{|r|}{$\begin{array}{l}\text { The player to be analyzed is the } 1 \text { st or } 2 \text { nd partner closest to the player with } \\
\text { possession (including goalkeeper) }\end{array}$} \\
\hline & $\begin{array}{l}\text { Attacker without the } \\
\text { ball out of the game } \\
\text { center }\end{array}$ & Asb:a & \multicolumn{2}{|r|}{$\begin{array}{l}\text { The player to be analyzed is not the } 1 \text { st or } 2 \text { nd partner closest to the player } \\
\text { with possession (including goalkeeper) }\end{array}$} \\
\hline & $\begin{array}{l}\text { Defender in the } \\
\text { intervention space }\end{array}$ & Dacb & \multicolumn{2}{|r|}{ The player to be analyzed is the closest to the attacker with the ball } \\
\hline & $\begin{array}{l}\text { Defender in game } \\
\text { center }\end{array}$ & D:C & \multirow{2}{*}{\multicolumn{2}{|c|}{$\begin{array}{l}\text { The player to be analyzed is the } 2 \text { nd or } 3 \text { rd opponent closest to the attacker } \\
\text { with the ball (including goalkeeper) } \\
\text { The player to be analyzed is not the } 1 \text { st, } 2 \text { nd or } 3 \text { rd opponent closest to the } \\
\text { attacker with the ball (including goalkeeper) }\end{array}$}} \\
\hline & $\begin{array}{l}\text { Defender out of } \\
\text { game center }\end{array}$ & D:a & & \\
\hline \multirow{16}{*}{$\begin{array}{l}\text { Actions of } \\
\text { the } \\
\text { acquired } \\
\text { subroles }\end{array}$} & \multirow{2}{*}{ Ball control } & \multirow{2}{*}{ RECEP } & & $\begin{array}{l}\text { Successful tactical behavior: Profiling oneself with body orientation to } \\
\text { receive, maintaining the ball after the first contact }\end{array}$ \\
\hline & & & & $\begin{array}{l}\text { Wrong tactical behavior: Failing to profile prior to receive the ball or } \\
\text { not holding the ball after the first contact }\end{array}$ \\
\hline & Driving & COND & & $\begin{array}{l}\text { Successful tactical behavior: Moving with the ball by making at least } 3 \\
\text { contacts after the previous control and maintaining possession }\end{array}$ \\
\hline & & & & $\begin{array}{l}\text { Wrong tactical behavior: Moving with the ball by making at least } 3 \\
\text { contacts after the previous control and losing possession }\end{array}$ \\
\hline & Dribble & DRIB & & $\begin{array}{l}\text { Successful tactical behavior: Surpass the adversary, avoid the } \\
\text { opponent's tackle while maintaining possession of the ball, or receive } \\
\text { foul having the ball }\end{array}$ \\
\hline & & & $*$ & $\begin{array}{l}\text { Wrong tactical behavior: Losing possession of the ball when trying to } \\
\text { surpass the opponent }\end{array}$ \\
\hline & Passing & PASE & & $\begin{array}{l}\text { Successful tactical behavior: Maintaining possession of the ball or } \\
\text { creating a dangerous situation by sending the ball to a teammate }\end{array}$ \\
\hline & & & 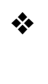 & $\begin{array}{l}\text { Wrong tactical behavior: Losing possession of the ball or not creating a } \\
\text { dangerous situation by trying to send the ball to a teammate }\end{array}$ \\
\hline & Shooting & TIRO & & $\begin{array}{l}\text { Successful tactical behavior: Kicking the ball towards the goal with the } \\
\text { intention of scoring or receiving a foul while attempting to score }\end{array}$ \\
\hline & & & & $\begin{array}{l}\text { Wrong tactical behavior: Failure to kick the ball on goal or lose } \\
\text { possession of the ball at the time of preparation to kick on goal }\end{array}$ \\
\hline & Move off-the-ball & DESM & & $\begin{array}{l}\text { Successful tactical behavior: Move to a favorable area to score a goal or } \\
\text { to a free space in front of the ball giving a passing line to the teammate }\end{array}$ \\
\hline & & & 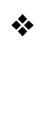 & $\begin{array}{l}\text { Wrong tactical behavior: Moving in front of the ball to an occupied } \\
\text { space and/or not giving a passing line, except for areas conducive to } \\
\text { scoring a goal. }\end{array}$ \\
\hline & Positioning & POSI & & $\begin{array}{l}\text { Successful tactical behavior: Support your partner with the ball, either } \\
\text { on his back, left or right; or give width-length to the team without } \\
\text { intention to receive immediately. }\end{array}$ \\
\hline & & & & $\begin{array}{l}\text { Wrong tactical behavior: Being too far from the teammate with the ball, } \\
\text { without giving width or length to the team, not being able to offer pass } \\
\text { options or offensive coverage in case of loss. }\end{array}$ \\
\hline & Tackling & ENTR & & $\begin{array}{l}\text { Successful tactical behavior: Contact the ball or the opponent, avoiding } \\
\text { being overtaken by dribbling or making him miss }\end{array}$ \\
\hline & & & 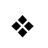 & Wrong tactical behavior: Being overtaken by dribbling or making a foul \\
\hline
\end{tabular}


Table 2. Cont.

\begin{tabular}{|c|c|c|c|}
\hline Criterion & Category & Code & Definition for Observation \\
\hline & \multirow[t]{2}{*}{ Interception } & \multirow{2}{*}{ INTER } & $\begin{array}{l}\text { Successful tactical behavior: Changing the direction of the ball by } \\
\text { cutting, clearing, or deflecting a pass or shot }\end{array}$ \\
\hline & & & $\begin{array}{l}\text { Wrong tactical behavior: Trying to cut, clear or deflect a pass or shot } \\
\text { without contacting the ball or preventing it from reaching its } \\
\text { destination (opponent or goal) }\end{array}$ \\
\hline & \multirow[t]{2}{*}{ Dissuading } & \multirow[t]{2}{*}{ DISU } & $\begin{array}{l}\text { Successful tactical behavior: Condition the opponent's attack without } \\
\text { contacting the ball or the opponent, preventing progression or } \\
\text { finishing on goal }\end{array}$ \\
\hline & & & $\begin{array}{l}\text { Wrong tactical behavior: Trying to condition the opponent's attack } \\
\text { without contacting the ball or the opponent, not preventing } \\
\text { progression or finishing on goal }\end{array}$ \\
\hline & \multirow[t]{2}{*}{ Relocating } & \multirow{2}{*}{ RECOL } & $\begin{array}{l}\checkmark \text { Successful tactical conduct: Protect the goal by marking or watching } \\
\text { for potential receivers, or being on the last defensive line }\end{array}$ \\
\hline & & & $\begin{array}{l}\text { Wrong tactical behavior: Neglecting the protection of the goal by not } \\
\text { marking or watching for potential receivers, or not being in the last } \\
\text { defensive line }\end{array}$ \\
\hline \multirow{3}{*}{$\begin{array}{l}\text { Result of } \\
\text { the action }\end{array}$} & Successful & YES & \multirow{3}{*}{$\begin{array}{l}\text { The tactical behavior performed by the player according to his subrole is } \\
\text { successful } \\
\text { The tactical behavior performed by the player according to his subrole } \\
\text { cannot be identified as clearly successful or wrong. } \\
\text { The tactical behavior performed by the player according to his subrole is } \\
\text { wrong }\end{array}$} \\
\hline & Improvable & DUDA & \\
\hline & Wrong & $\mathrm{NO}$ & \\
\hline \multirow{6}{*}{$\begin{array}{l}\text { Operational } \\
\text { principle }\end{array}$} & $\begin{array}{l}\text { Maintain ball } \\
\text { possession }\end{array}$ & AT1 & \multirow{2}{*}{$\begin{array}{l}\text { For the player with the ball: Control from behind or at the same height as the } \\
\text { previous action in the own field; pass, drive or dribble without advancing } \\
\text { towards the opponent's goal. } \\
\text { For the player without the ball: Move or position behind the ball or at the } \\
\text { same height in the own field, or in the rival field without the immediate } \\
\text { objective of receiving to score. } \\
\text { For the player with the ball: Control ahead of the previous action, or driving, } \\
\text { passing, dribbling moving towards the opponent's goal (except for all } \\
\text { behaviors in rival field or against the last defender or exceeded this one) } \\
\text { For the player without the ball: Moving in front of the ball in the own field } \\
\text { or positioning in the rival field without the immediate objective of receiving } \\
\text { to score a goal. }\end{array}$} \\
\hline & $\begin{array}{l}\text { Progress towards } \\
\text { rival area }\end{array}$ & AT2 & \\
\hline & Achieving the goal & AT3 & $\begin{array}{l}\text { For the player with the ball: Control, drive, pass, or dribble in the rival field } \\
\text { or against the last defender (or past this one) and shoot } \\
\text { For the player without the ball: Move in the rival field with the immediate } \\
\text { objective of receiving the ball. }\end{array}$ \\
\hline & Regain Possession & DF1 & \multirow{2}{*}{$\begin{array}{l}\text { Tackling the attacker with the ball or intercepting a pass } \\
\text { Relocating in the last defensive line, or dissuading in the opposite field by } \\
\text { not allowing the advance of the ball, giving coverage to the teammate, } \\
\text { balancing the center of play or reducing the effective playing space }\end{array}$} \\
\hline & $\begin{array}{l}\text { Prevent opponent's } \\
\text { progression }\end{array}$ & DF2 & \\
\hline & Protect the goal & DF3 & $\begin{array}{l}\text { Relocating increasing the protection of the goal, dissuading in the own field } \\
\text { when the attacker with the ball is going to shoot or intercept a shot }\end{array}$ \\
\hline \multirow{3}{*}{$\begin{array}{l}\text { Specific } \\
\text { principle }\end{array}$} & Penetration & AT:P1 & \multirow{3}{*}{$\begin{array}{l}\text { The player to be analyzed displays a behavior with the ball with the } \\
\text { intention of progressing towards the opposite goal or finishing directly } \\
\text { (shooting) or indirectly (assisting a teammate in the end zone) } \\
\text { The player to be analyzed does not have possession of the ball, and is in the } \\
\text { center of the game behind the ball or at the same height } \\
\text { The player to be analyzed does not have possession of the ball and is in front } \\
\text { of it with the intention of receiving }\end{array}$} \\
\hline & Offensive coverage & AT:P2 & \\
\hline & Depth mobility & AT:P3 & \\
\hline
\end{tabular}


Table 2. Cont.

\begin{tabular}{|c|c|c|c|}
\hline Criterion & Category & Code & Definition for Observation \\
\hline & Width and length & AT:P4 & $\begin{array}{l}\text { The player to be analyzed displays a behavior with the ball without the } \\
\text { intention of progressing towards the opposite goal or finishing directly } \\
\text { (shooting) or indirectly (assisting a teammate in the end zone) } \\
\text { The player to be analyzed does not have possession of the ball, is not in the } \\
\text { center of the game, or in the last defensive line, and does not intend to } \\
\text { receive immediately }\end{array}$ \\
\hline & Offensive unity & AT:P5 & $\begin{array}{l}\text { The player to be analyzed does not have possession of the ball and is in the } \\
\text { last line of the team without including the goalkeeper }\end{array}$ \\
\hline & Delay & DF:P1 & The player to be analyzed is the closest to the attacker with the ball \\
\hline & Defensive coverage & DF:P2 & $\begin{array}{l}\text { The player to be analyzed is in the game center behind the teammate who } \\
\text { performs the delay }\end{array}$ \\
\hline & Balance & DF:P3 & $\begin{array}{l}\text { The player to be analyzed goes to the game center with the intention of } \\
\text { creating superiority or is in the game center ahead of the ball }\end{array}$ \\
\hline & Concentration & DF:P4 & $\begin{array}{l}\text { The player to be analyzed is not in the game center and is in the last line of } \\
\text { the team without including the goalkeeper }\end{array}$ \\
\hline & Defensive unity & DF:P5 & $\begin{array}{l}\text { The player to be analyzed is not in the game center and is not in the last line } \\
\text { of the team without including the goalkeeper }\end{array}$ \\
\hline
\end{tabular}

\subsection{Procedure}

The instrument design, the validity and reliability processes were carried out in six stages (see Figure 1) following the procedures used in other recent observational tools [22,45,46]: (a) bibliographic review and provisional design of the tool observation system, (b) consultation with experts, reconfiguration of the tool observation system and choice of reference formats for the game protocol, (c) content validation of the coding instrument, (d) simplification of the coding instrument and validation of this process, (e) development of intra-observer and inter-observer reliability processes in addition to generalizability analysis and (f) calculation of construct validity. Finally, the quality of this process was assessed using the methodological quality checklist for studies based on observational methodology (MQCOM) [47].

In the first stage, the provisional selection of the criteria and observation categories that make up the tool was carried out through a bibliographic review of the main evaluation tools of the PTK [16-18,20,21], as well as studies and observation tools designed from the football player's subroles [28,29].

In the second stage, the observation system was gradually modified after consultation with experts. Using a Likert scale of 1-10, they were asked about: (a) degree of agreement, regarding clarity of language in the definition of the criteria and categories of the tool; (b) degree of importance and adequacy, based on practical and theoretical relevance, when the criterion or category to evaluate was part of the tool; (c) considerations, comments and observations about each criterion and categories of the tool. In this way, the criteria and categories were reconfigured, shaping the observation system of the tool and subjecting it to a new expert judgment, until passing the validation process in the third phase.

Parallel to this process, and taking the observation system proposed, an ad-hoc observational tool was designed for the coding and data collection process using the "LINCE software" [48]. Subsequently, templates were designed using Microsoft Excel 365 (Microsoft Corporation, Washington, USA) for the analysis and treatment of the data obtained, which would also be adapted during the process until obtaining the final version. From the observation tool, several simulations were performed and codified using different protocols and players to identify possible aspects to improve, which could be added to the experts' judgment.

The choice of the reference formats that would serve as a protocol for the analysis of the PTK of the players tried to respond both to 7-football (for players U12), and to 11-football (from U13). For this, the player's theoretical individual space of interaction was considered; that is, $300 \mathrm{~m}^{2}$ for 11 -football and $200 \mathrm{~m}^{2}$ for 7 -football [49]. These values 
served as a reference for the construction of the protocols considering the age of the players to be analyzed. Two protocols, based on SSG Gk $+4 \mathrm{v} 4+\mathrm{Gk}$, were established according to the football modality. As a result of this, easily identifiable spaces were established within the playing field, as well as playing times, in order to minimize the effect of fatigue during the protocol, establishing the following game formats that would serve as a reference for its realization (see Table 3).

1 - BIBLIOGRAPHIC REVIEW \& PROVISIONAL OBSERVATION SYSTEM
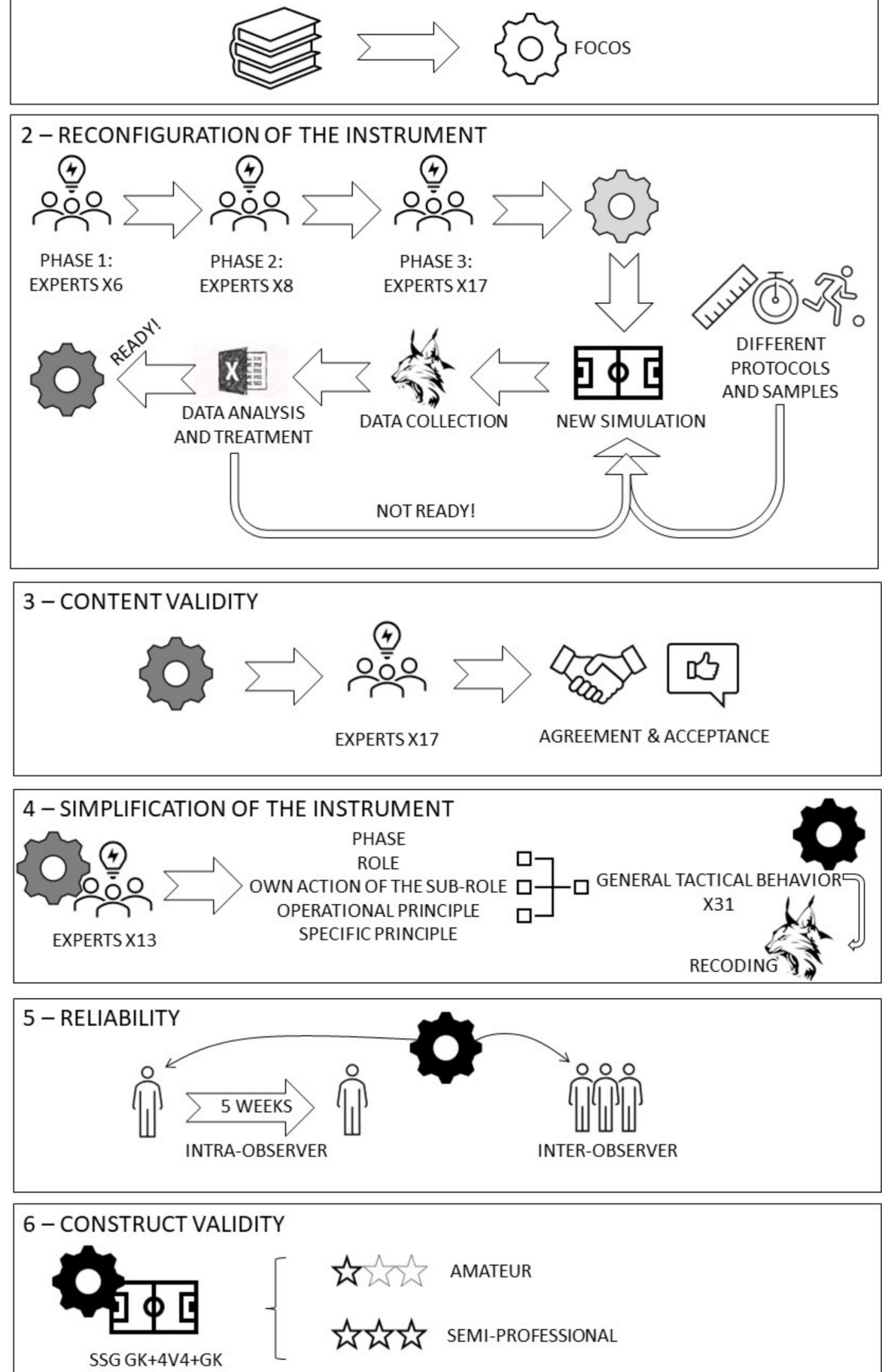

Figure 1. Stages for the design and validation of FOCOS. 
Table 3. Reference formats for carrying out the protocol.

\begin{tabular}{cccccc}
\hline Category & Players & Goals Sizes & Space: Length $\times$ Width & $\begin{array}{c}\text { Individual Space } \\
\text { of Interaction }\end{array}$ & $\begin{array}{c}\text { Duration: Series } \times \\
\text { Minutes/Break } \\
\text { between Series }\end{array}$ \\
\hline Up to U12 & GK $+4 \mathrm{v} 4+\mathrm{Gk}$ & $6 \times 2 \mathrm{~m}$ & $\begin{array}{c}\text { Half field }(7 \text {-football) } \\
25 \times 30 \mathrm{~m}(\text { minimum) }\end{array}$ & $94 \mathrm{~m}^{2}$ & $2 \times 4^{\prime} / 1^{\prime}$ \\
\hline From U13 & $\mathrm{Gk}+4 \mathrm{v} 4+\mathrm{Gk}$ & $7.32 \times 2.44 \mathrm{~m}$ & $\begin{array}{c}\text { Double area }(11 \text {-football) } \\
33 \times 40 \mathrm{~m}\end{array}$ & $165 \mathrm{~m}^{2}$ & $2 \times 4^{\prime} / 1^{\prime}$ \\
\hline
\end{tabular}

In the third stage, the content validity of the instrument was established from the last group of experts $(n=17)$ through the Content Validity Coefficient (CVC) [50]. Once the opinion of this last group of experts was obtained, the categories of the observational system with average values $<0.70$, in terms of degree of agreement or degree of acceptance, were eliminated $(n=0)$; the categories with values between 0.70 and 0.80 were reformulated following the proposals of the experts $(n=1)$ and the categories with average values greater than 0.8 were accepted $(n=36)$ [51]. In this sense, practically all the categories had average values above 0.80 since the tool had undergone a rigorous configuration process before reaching this point. However, based on the considerations provided by the experts, a new category was included within the criterion result of the action (category $=$ improvable). Football is a sport of maximum uncertainty, where unrepeatable behaviors occur. This new category seems important, when the observer cannot identify with certainty whether the behavior performed by the player is successful or not.

In the fourth stage, to simplify the instrument and increase its agility, the number of criteria in the analysis tool was reduced to two, unifying the phase, role, own action of the subrole, operational principle and specific principle in a single criterion called "general tactical behavior", and maintaining the criterion "result of the action". To carry out this process, the networks of mutually compatible categories were validated, discarding those combinations that were impossible in the game (examples: an attacker without the ball could never make a pass, or a defender could never perform the specific principle of penetration). Once this was complete, the 315 combinations of categories of the criteria in attack and the 180 combinations in defense were presented to a last group of experts $(n=13)$. The experts had to show their degree of agreement and acceptance through a Likert 1-10 scale with those combinations proposed as compatible by the experimenter, propose new compatible combinations if any, and accept or reformulate the general tactical behavior name proposed for each one. From this process, combinations with values below 8 out of 10 should be discarded or reformulated following the contributions and comments of the experts [50]. In the case of the tool, a combination that did not reach the predetermined values was discarded, a new one was approved and 11 general tactical behaviors' names were reformulated after consultation with experts, even though all of them had exceeded the predetermined values. After this process, 21 attack and 10 defense combinations were proposed as compatible, providing an identifying name for each in the form of general tactical behavior. Table 4 shows the network of combinations described.

After the observational system was validated, the observation tool was codified again, this time using the new "LINCE PLUS software" [52].

In the fifth stage, the inter-and intra-observer reliability process were performed. For this, the procedures developed in other works were followed [53-56]. First, the conceptual and registration protocol for motor behaviors was developed. Secondly, two observers were trained according to said protocol, and carried out the analysis of a determined player independently, who was previously analyzed by the experimenter. Third, inter-observer reliability was calculated, and the behaviors analyzed as different between observers were discussed and re-analyzed. Five weeks later, through the test-retest reliability method, an observer repeated the analysis process and the results obtained were compared with their previous analysis to calculate intra-observation reliability. Given the nature of the data 
analyzed and to control their quality, the TG (Generalizability Theory) [57] was applied from the modeling of the different sources of variability or facets (e.g., observers and categories of the taxonomic system), designing two possible models: Categories:Observers $[\mathrm{C}: \mathrm{O}]$ and Observers:Categories [O:C].

Table 4. General tactical behaviors in the network of compatible category combinations in attack and defense.

\begin{tabular}{|c|c|c|c|c|c|c|c|}
\hline & Phase & Role & $\begin{array}{l}\text { Own } \\
\text { Action of } \\
\text { the } \\
\text { Sub-Role }\end{array}$ & $\begin{array}{l}\text { Operational } \\
\text { Principle }\end{array}$ & $\begin{array}{l}\text { Specific } \\
\text { Principle }\end{array}$ & General Tactical Behavior & $\begin{array}{l}\text { Combination } \\
\text { Code }\end{array}$ \\
\hline 1 & Attack & $\begin{array}{l}\text { Attacker with } \\
\text { the ball }\end{array}$ & Ball control & $\begin{array}{c}\text { Progress } \\
\text { towards rival } \\
\text { area }\end{array}$ & Penetration & $\begin{array}{l}\text { Control the ball ahead of } \\
\text { previous action }\left(^{*}\right)\end{array}$ & P Recep Pen \\
\hline 2 & Attack & $\begin{array}{l}\text { Attacker with } \\
\text { the ball }\end{array}$ & Ball control & $\begin{array}{l}\text { Maintain ball } \\
\text { possession }\end{array}$ & $\begin{array}{l}\text { Width and } \\
\text { length }\end{array}$ & $\begin{array}{l}\text { Control the ball at the same } \\
\text { height or behind the previous } \\
\text { action }(*)\end{array}$ & M Recep Esp \\
\hline 3 & Attack & $\begin{array}{l}\text { Attacker with } \\
\text { the ball }\end{array}$ & Ball control & $\begin{array}{l}\text { Achieving } \\
\text { the goal }\end{array}$ & Penetration & $\begin{array}{l}\text { Control the ball in the rival } \\
\text { area or in front of the last } \\
\text { defender (or surpassed this } \\
\text { one) }\end{array}$ & F Recep Pen \\
\hline 4 & Attack & $\begin{array}{l}\text { Attacker with } \\
\text { the ball }\end{array}$ & Driving & $\begin{array}{c}\text { Progress } \\
\text { towards rival } \\
\text { area }\end{array}$ & Penetration & Driving the ball forward $(*)$ & P Cond Pen \\
\hline 5 & Attack & $\begin{array}{l}\text { Attacker with } \\
\text { the ball }\end{array}$ & Driving & $\begin{array}{l}\text { Maintain ball } \\
\text { possession }\end{array}$ & $\begin{array}{l}\text { Width and } \\
\text { length }\end{array}$ & $\begin{array}{l}\text { Driving the ball backwards, } \\
\text { right, or left }\left(^{*}\right)\end{array}$ & M Cond Esp \\
\hline 6 & Attack & $\begin{array}{l}\text { Attacker with } \\
\text { the ball }\end{array}$ & Driving & $\begin{array}{l}\text { Achieving } \\
\text { the goal }\end{array}$ & Penetration & $\begin{array}{l}\text { Driving the ball in the rival } \\
\text { area or in front of the last } \\
\text { defender (or surpassed this } \\
\text { one) }\end{array}$ & F Cond Pen \\
\hline 7 & Attack & $\begin{array}{l}\text { Attacker with } \\
\text { the ball }\end{array}$ & Dribble & $\begin{array}{l}\text { Progress } \\
\text { towards rival } \\
\text { area }\end{array}$ & Penetration & Dribble to beat the rival $\left({ }^{*}\right)$ & P Drib Pen \\
\hline 8 & Attack & $\begin{array}{l}\text { Attacker with } \\
\text { the ball }\end{array}$ & Dribble & $\begin{array}{l}\text { Maintain ball } \\
\text { possession }\end{array}$ & $\begin{array}{l}\text { Width and } \\
\text { length }\end{array}$ & $\begin{array}{l}\text { Dribble without progress } \\
\text { avoiding rival tackle }(*)\end{array}$ & M Drib Esp \\
\hline 9 & Attack & $\begin{array}{l}\text { Attacker with } \\
\text { the ball }\end{array}$ & Dribble & $\begin{array}{l}\text { Achieving } \\
\text { the goal }\end{array}$ & Penetration & $\begin{array}{l}\text { Dribble in the rival area or in } \\
\text { front of the last defender (or } \\
\text { surpassed this one) }\end{array}$ & F Drib Pen \\
\hline 10 & Attack & $\begin{array}{l}\text { Attacker with } \\
\text { the ball }\end{array}$ & Passing & $\begin{array}{c}\text { Progress } \\
\text { towards rival } \\
\text { area }\end{array}$ & Penetration & $\begin{array}{l}\text { Pass the ball forward (except } \\
\text { to assist) }\end{array}$ & P Pas Pen \\
\hline 11 & Attack & $\begin{array}{l}\text { Attacker with } \\
\text { the ball }\end{array}$ & Passing & $\begin{array}{l}\text { Maintain ball } \\
\text { possession }\end{array}$ & $\begin{array}{l}\text { Width and } \\
\text { length }\end{array}$ & $\begin{array}{l}\text { Pass the ball backward, right, } \\
\text { or left (except to assist) }\end{array}$ & M Pas Esp \\
\hline 12 & Attack & $\begin{array}{l}\text { Attacker with } \\
\text { the ball }\end{array}$ & Passing & $\begin{array}{l}\text { Achieving } \\
\text { the goal }\end{array}$ & Penetration & Assist teammate to score goal & Asistir \\
\hline 13 & Attack & $\begin{array}{l}\text { Attacker with } \\
\text { the ball }\end{array}$ & Shooting & $\begin{array}{l}\text { Achieving } \\
\text { the goal }\end{array}$ & Penetration & Shoot at goal & Tirar \\
\hline 14 & Attack & $\begin{array}{l}\text { Attacker } \\
\text { without the } \\
\text { ball in the } \\
\text { game center }\end{array}$ & $\begin{array}{c}\text { Move } \\
\text { off-the-ball }\end{array}$ & $\begin{array}{l}\text { Progress } \\
\text { towards rival } \\
\text { area }\end{array}$ & $\begin{array}{l}\text { Depth } \\
\text { mobility }\end{array}$ & $\begin{array}{l}\text { Move giving close option } \\
\text { ahead of the ball }\end{array}$ & $\begin{array}{l}\text { P Desm } \\
\text { Cerca }\end{array}$ \\
\hline 15 & Attack & $\begin{array}{l}\text { Attacker } \\
\text { without the } \\
\text { ball in the } \\
\text { game center }\end{array}$ & $\begin{array}{c}\text { Move } \\
\text { off-the-ball }\end{array}$ & $\begin{array}{l}\text { Achieving } \\
\text { the goal }\end{array}$ & $\begin{array}{l}\text { Depth } \\
\text { mobility }\end{array}$ & $\begin{array}{l}\text { Appear in a space suitable to } \\
\text { scoring a goal (near the } \\
\text { teammate with the ball) }\end{array}$ & $\begin{array}{l}\text { F Desm } \\
\text { Cerca }\end{array}$ \\
\hline 16 & Attack & $\begin{array}{l}\text { Attacker } \\
\text { without the } \\
\text { ball in the } \\
\text { game center }\end{array}$ & Positioning & $\begin{array}{l}\text { Maintain ball } \\
\text { possession }\end{array}$ & $\begin{array}{l}\text { Offensive } \\
\text { coverage }\end{array}$ & $\begin{array}{l}\text { Take care of the back of the } \\
\text { partner with the ball or give } \\
\text { option close to the right/left }\end{array}$ & M Posi Esp \\
\hline
\end{tabular}


Table 4. Cont.

\begin{tabular}{|c|c|c|c|c|c|c|c|}
\hline & Phase & Role & $\begin{array}{l}\text { Own } \\
\text { Action of } \\
\text { the } \\
\text { Sub-Role }\end{array}$ & $\begin{array}{l}\text { Operational } \\
\text { Principle }\end{array}$ & $\begin{array}{l}\text { Specific } \\
\text { Principle }\end{array}$ & General Tactical Behavior & $\begin{array}{l}\text { Combination } \\
\text { Code }\end{array}$ \\
\hline 17 & Attack & $\begin{array}{l}\text { Attacker } \\
\text { without the } \\
\text { ball out of the } \\
\text { game center }\end{array}$ & $\begin{array}{c}\text { Move } \\
\text { off-the-ball }\end{array}$ & $\begin{array}{c}\text { Progress } \\
\text { towards rival } \\
\text { area }\end{array}$ & $\begin{array}{l}\text { Depth } \\
\text { mobility }\end{array}$ & $\begin{array}{l}\text { Move away from the ball } \\
\text { appearing between rival lines } \\
\text { or behind the defense }\end{array}$ & P Desm Lejos \\
\hline 18 & Attack & $\begin{array}{l}\text { Attacker } \\
\text { without the } \\
\text { ball out of the } \\
\text { game center }\end{array}$ & $\begin{array}{l}\text { Move } \\
\text { off-the-ball }\end{array}$ & $\begin{array}{l}\text { Achieving } \\
\text { the goal }\end{array}$ & $\begin{array}{l}\text { Depth } \\
\text { mobility }\end{array}$ & $\begin{array}{l}\text { Appear in a space suitable to } \\
\text { scoring a goal (away from the } \\
\text { teammate with the ball) }\end{array}$ & F Desm Lejos \\
\hline 19 & Attack & $\begin{array}{l}\text { Attacker } \\
\text { without the } \\
\text { ball out of the } \\
\text { game center }\end{array}$ & Positioning & $\begin{array}{c}\text { Progress } \\
\text { towards rival } \\
\text { area }\end{array}$ & $\begin{array}{l}\text { Width and } \\
\text { length }\end{array}$ & $\begin{array}{l}\text { Give depth to the attack by } \\
\text { positioning in length }\end{array}$ & P Posi Prof \\
\hline 20 & Attack & $\begin{array}{l}\text { Attacker } \\
\text { without the } \\
\text { ball out of the } \\
\text { game center }\end{array}$ & Positioning & $\begin{array}{l}\text { Maintain ball } \\
\text { possession }\end{array}$ & $\begin{array}{l}\text { Width and } \\
\text { length }\end{array}$ & $\begin{array}{l}\text { Give amplitude to the attack } \\
\text { by positioning in width }\end{array}$ & M Posi Ampl \\
\hline 21 & Attack & $\begin{array}{l}\text { Attacker } \\
\text { without the } \\
\text { ball out of the } \\
\text { game center }\end{array}$ & Positioning & $\begin{array}{l}\text { Maintain ball } \\
\text { possession }\end{array}$ & $\begin{array}{l}\text { Offensive } \\
\text { unity }\end{array}$ & $\begin{array}{l}\text { Relocate in coordination with } \\
\text { the teammates on the last line }\end{array}$ & M Posi UO \\
\hline 22 & Defense & $\begin{array}{l}\text { Defender in } \\
\text { the } \\
\text { intervention } \\
\text { space }\end{array}$ & Tackling & $\begin{array}{l}\text { Regain } \\
\text { Possession }\end{array}$ & Delay & Make a tackle to the rival & Entrar \\
\hline 23 & Defense & $\begin{array}{l}\text { Defender in } \\
\text { the } \\
\text { intervention } \\
\text { space }\end{array}$ & Interception & $\begin{array}{l}\text { Regain } \\
\text { Possession }\end{array}$ & Delay & $\begin{array}{l}\text { Intercept, clear or divert a } \\
\text { pass }\end{array}$ & Interc \\
\hline 24 & Defense & $\begin{array}{l}\text { Defender in } \\
\text { the } \\
\text { intervention } \\
\text { space }\end{array}$ & Interception & $\begin{array}{l}\text { Protect the } \\
\text { goal }\end{array}$ & Delay & Block a shot & Bloq \\
\hline 25 & Defense & $\begin{array}{l}\text { Defender in } \\
\text { the } \\
\text { intervention } \\
\text { space }\end{array}$ & Dissuading & $\begin{array}{l}\text { Prevent } \\
\text { opponent's } \\
\text { progression }\end{array}$ & Delay & Redirect the opponent's attack & Redir \\
\hline 26 & Defense & $\begin{array}{l}\text { Defender in } \\
\text { the } \\
\text { intervention } \\
\text { space }\end{array}$ & Dissuading & $\begin{array}{l}\text { Protect the } \\
\text { goal }\end{array}$ & Delay & $\begin{array}{l}\text { Do not give the opponent a } \\
\text { shot option without entering } \\
\text { him (avoid possible shot) }\end{array}$ & Disu Tiro \\
\hline 27 & Defense & $\begin{array}{l}\text { Defender in } \\
\text { game center }\end{array}$ & Dissuading & $\begin{array}{l}\text { Prevent } \\
\text { opponent's } \\
\text { progression }\end{array}$ & $\begin{array}{l}\text { Defensive } \\
\text { coverage }\end{array}$ & $\begin{array}{l}\text { Take care of the partner's back } \\
\text { in the intervention space in a } \\
\text { staggered manner }\end{array}$ & Cober \\
\hline 28 & Defense & $\begin{array}{l}\text { Defender in } \\
\text { game center }\end{array}$ & Dissuading & $\begin{array}{l}\text { Prevent } \\
\text { opponent's } \\
\text { progression }\end{array}$ & Balance & $\begin{array}{l}\text { Move to create superiority in } \\
\text { the game center or } \\
\text { mark/watch opponents }\end{array}$ & Equi \\
\hline 29 & Defense & $\begin{array}{l}\text { Defender out } \\
\text { of game } \\
\text { center }\end{array}$ & Dissuading & $\begin{array}{l}\text { Prevent } \\
\text { opponent's } \\
\text { progression }\end{array}$ & $\begin{array}{l}\text { Defensive } \\
\text { unity }\end{array}$ & $\begin{array}{l}\text { Create uncertainty in the last } \\
\text { opponent line or reduce the } \\
\text { effective playing space }\end{array}$ & Reple \\
\hline 30 & Defense & $\begin{array}{l}\text { Defender out } \\
\text { of game } \\
\text { center }\end{array}$ & Relocating & $\begin{array}{l}\text { Protect the } \\
\quad \text { goal }\end{array}$ & $\begin{array}{l}\text { Defensive } \\
\text { unity }\end{array}$ & $\begin{array}{l}\text { Relocation in the last } \\
\text { defensive line reducing the } \\
\text { effective playing space }\end{array}$ & Recol \\
\hline 31 & Defense & $\begin{array}{l}\text { Defender out } \\
\text { of game } \\
\text { center }\end{array}$ & Relocating & $\begin{array}{l}\text { Protect the } \\
\text { goal }\end{array}$ & Concentration & $\begin{array}{l}\text { Increase the protection of the } \\
\text { goal, marking or watching } \\
\text { opponents }\end{array}$ & Concen \\
\hline
\end{tabular}

$\left.{ }^{*}\right)$ Except in the rival field. 
Finally, in the sixth stage, once a high content validity for the instrument was obtained and the reliability processes were overcome, the construct validity of the instrument was calculated, in its perspective of discriminant validity, to measure the degree of the instrument to distinguish between groups of players that are expected to be different [58].

\subsection{Application}

After using FOCOS to carry out the PTK analysis of the players taking part in the selected protocol, the data obtained from each player were transferred to Excel templates designed ad-hoc to obtain the resulting scores and to perform the consequent evaluation. In these templates, data processing is performed to obtain the volume and the effectiveness index of each variable within the criteria studied. Volume is understood as the number of times the player develops tactical behaviors in which each category is involved, while the effectiveness index is represented by the volume of successful tactical behaviors divided by the number of tactical behaviors deployed by the player in the category of analysis studied.

Once the effectiveness indices have been obtained for each category, the offensive and defensive effectiveness indices are calculated, as well as a global effectiveness index. This global effectiveness index represents the player's PTK level. In short, general scores are obtained for these last three mentioned variables, together with the specific scores of the variables that represent the categories of the role criteria, own action of the subrole and operational and specific principle of the FOCOS. All these specific scores are also compared with the average scores of all the analyzed players, allowing the determination of the player's PTK level in each variable with respect to the teammates in their group. In addition, the scores of the variables are shown in the form of general tactical behaviors in game-play situations in which the player has developed them.

\subsection{Data Analysis}

The coding instrument has been evaluated in relation to the quality of the data required of any observational research that purports to be scientific [59]. To do this, the content validity of the instrument has been approached qualitatively, through consensual agreement [60] of a group of experts, through the Delphi method and using the content validity coefficient [50]. It has also been analyzed quantitatively, by calculating intraobserver reliability, using Cohen's kappa; and inter-observer reliability, using the fleiss kappa index. Furthermore, the construct validity has been calculated using Student's $t$-test for independent samples.

\section{Results}

The verification of the quality of the observational data allows for subsequent objective studies, and in this way, the adoption of original strategies for their application in training [59]. The results are described in the following sections.

\subsection{Content Validity of the FOCOS}

To calculate the Content Validity Coefficient [50], the averages of the two factors used with the expert groups were calculated, following the Delphi methodology: the degree of agreement (8.74 out of 10) which reflects the clarity of the language (to what extent do you consider the definition to be well developed and exclusive with respect to the other categories of the criterion?), and the degree of adequacy (9.3 out of 10) which represents practical and theoretical relevance (to what extent do you consider that the category should be part of the criterion?). From these two factors, the total content validity of the tool was obtained (9.02 out of 10), concluding that it is a very high validity. In the same way, the criterion "General tactical behavior" was also validated. In this process, the global content validity was also very high (9.4 out of 10$)$. 


\subsection{Construct Validity of the FOCOS}

The construct validity of the instrument was calculated, in its perspective of discriminant validity, to measure the degree of the instrument to distinguish between groups of players that are expected to be different [58]. Using the reference formats, the protocol was carried out with two independent samples. Although all variables were analyzed, the overall total score, the total offensive score and the total defensive score obtained by semi-professional players were compared with the scores obtained by amateur players, since they reflect a more global vision of the players' football competence. The data were analyzed using the Student's $t$-test for independent samples and the results showed significant differences $(\alpha<0.05)$ between both groups in these three variables (see Table 5). Cohen's d-effect size [61] was also calculated to assess the magnitude of the difference between both groups. Differences based on effect size are referred to descriptively as very large $(\mathrm{d} \geq 2)$, large $(2.0>\mathrm{d} \geq 1.2)$, moderate $(1.2>\mathrm{d} \geq 0.6)$, small $(0.6>\mathrm{d} \geq 0.2)$ and trivial $(0.2>d \geq 0)$. [62] The results showed values between 1.08 and 2.32, except for one variable that showed significant differences in favor of the amateur group.

Table 5. Differences between semi-professional football players and amateur football players.

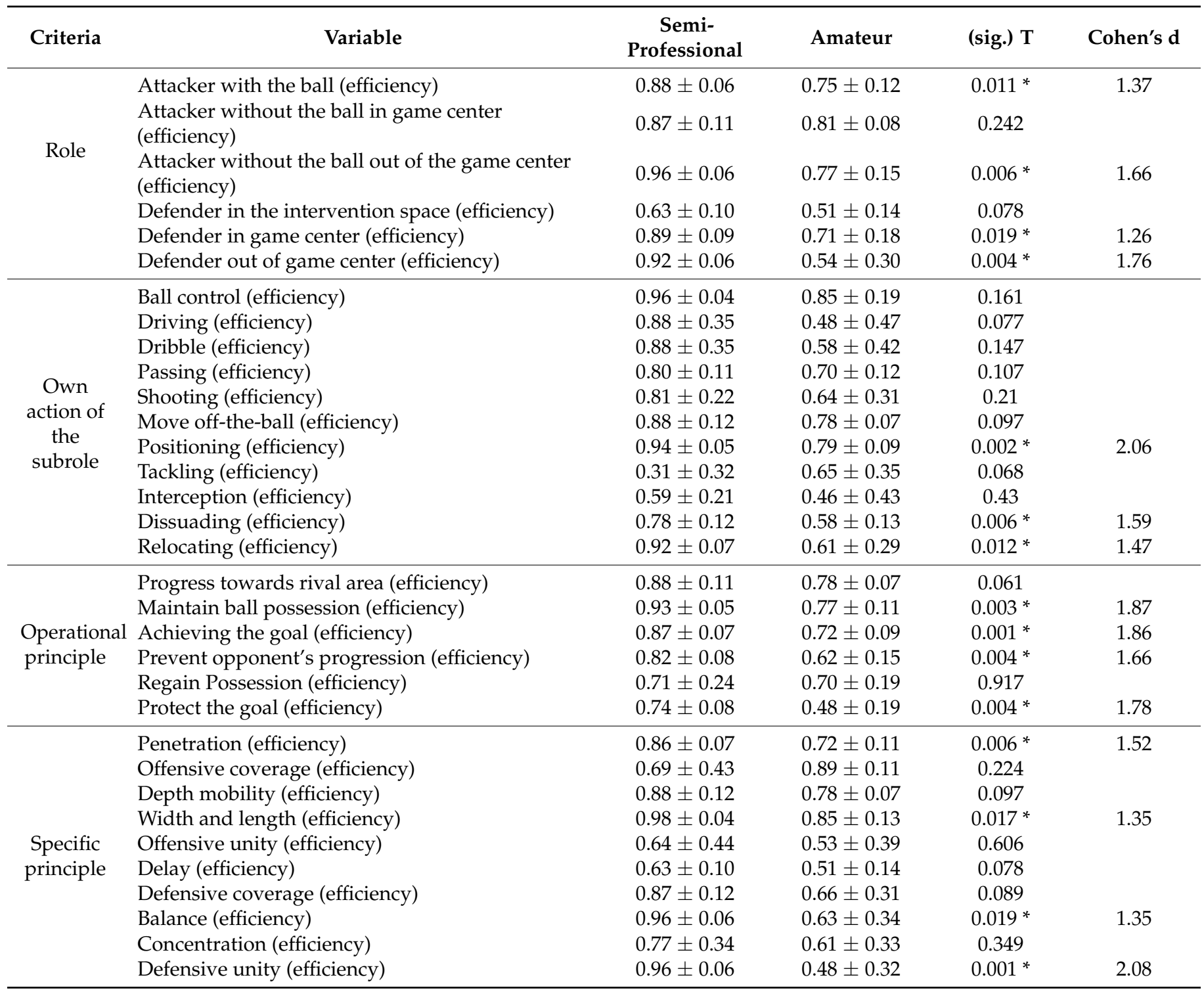


Table 5. Cont.

\begin{tabular}{|c|c|c|c|c|c|}
\hline Criteria & Variable & $\begin{array}{l}\text { Semi- } \\
\text { Professional }\end{array}$ & Amateur & (sig.) $\mathrm{T}$ & Cohen's d \\
\hline \multirow{31}{*}{$\begin{array}{l}\text { General } \\
\text { tactical } \\
\text { behavior }\end{array}$} & $\begin{array}{l}\text { Control the ball ahead of previous action }\left(^{*}\right) \\
\text { (efficiency) }\end{array}$ & $0.95 \pm 0.06$ & $0.97 \pm 0.07$ & 0.59 & \multirow{16}{*}{1.13} \\
\hline & $\begin{array}{l}\text { Control the ball at the same height or behind the } \\
\text { previous action }\left(^{*}\right) \text { (efficiency) }\end{array}$ & $0.75 \pm 0.46$ & $0.75 \pm 0.46$ & 1 & \\
\hline & $\begin{array}{l}\text { Control the ball in the rival area or in front of the } \\
\text { last defender (or surpassed this one) (efficiency) }\end{array}$ & $0.85 \pm 0.35$ & $0.55 \pm 0.39$ & 0.126 & \\
\hline & Driving the ball forward $(*)$ (efficiency) & $0.88 \pm 0.35$ & $0.38 \pm 0.52$ & $0.041 *$ & \\
\hline & $\begin{array}{l}\text { Driving the ball backwards, right, or left }\left(^{*}\right) \\
\text { (efficiency) }\end{array}$ & $0.88 \pm 0.35$ & $0.38 \pm 0.52$ & 0.041 & \\
\hline & $\begin{array}{l}\text { Driving the ball in the rival area or in front of the } \\
\text { last defender (or surpassed this one) (efficiency) }\end{array}$ & $0.00 \pm 0.00$ & $0.31 \pm 0.46$ & 0.074 & \\
\hline & Dribble to beat the rival ${ }^{*}$ ) (efficiency) & $0.38 \pm 0.52$ & $0.38 \pm 0.52$ & 1 & \\
\hline & $\begin{array}{l}\text { Dribble without progress avoiding rival tackle }\left(^{*}\right) \\
\text { (efficiency) }\end{array}$ & $0.50 \pm 0.53$ & $0.50 \pm 0.53$ & 1 & \\
\hline & $\begin{array}{l}\text { Dribble in the rival area or in front of the last } \\
\text { defender (or surpassed this one) (efficiency) }\end{array}$ & $0.38 \pm 0.52$ & $0.25 \pm 0.40$ & 0.598 & \\
\hline & Pass the ball forward (except to assist) (efficiency) & $0.71 \pm 0.35$ & $0.52 \pm 0.38$ & 0.291 & \\
\hline & $\begin{array}{l}\text { Pass the ball backward, right, or left (except to } \\
\text { assist) (efficiency) }\end{array}$ & $0.92 \pm 0.13$ & $0.66 \pm 0.44$ & 0.141 & \\
\hline & Assist teammate to score goal (efficiency) & $0.74 \pm 0.35$ & $0.63 \pm 0.32$ & 0.515 & \\
\hline & Shoot at goal (efficiency) & $0.81 \pm 0.22$ & $0.64 \pm 0.31$ & 0.21 & \\
\hline & $\begin{array}{l}\text { Move giving close option ahead of the ball } \\
\text { (efficiency) }\end{array}$ & $0.85 \pm 0.19$ & $0.67 \pm 0.32$ & 0.192 & \\
\hline & $\begin{array}{l}\text { Appear in a space suitable to scoring a goal (near } \\
\text { the teammate with the ball) (efficiency) }\end{array}$ & $0.95 \pm 0.09$ & $0.84 \pm 0.18$ & 0.164 & \\
\hline & $\begin{array}{l}\text { Take care of the back of the partner with the ball or } \\
\text { give option close to the right / left (efficiency) }\end{array}$ & $0.69 \pm 0.43$ & $0.89 \pm 0.11$ & 0.224 & \\
\hline & $\begin{array}{l}\text { Move away from the ball appearing between rival } \\
\text { lines or behind the defense (efficiency) }\end{array}$ & $0.84 \pm 0.35$ & $0.19 \pm 0.37$ & $0.003 *$ & \multirow[t]{3}{*}{1.8} \\
\hline & $\begin{array}{l}\text { Appear in a space suitable to scoring a goal (away } \\
\text { from the teammate with the ball) (efficiency) }\end{array}$ & $0.50 \pm 0.53$ & $0.57 \pm 0.40$ & 0.762 & \\
\hline & $\begin{array}{l}\text { Give depth to the attack by positioning in length } \\
\text { (efficiency) }\end{array}$ & $0.75 \pm 0.46$ & $0.62 \pm 0.51$ & 0.591 & \\
\hline & $\begin{array}{l}\text { Give amplitude to the attack by positioning in } \\
\text { width (efficiency) }\end{array}$ & $0.86 \pm 0.35$ & $0.39 \pm 0.42$ & $0.029 *$ & \multirow[t]{5}{*}{1.22} \\
\hline & $\begin{array}{l}\text { Relocate in coordination with the teammates on } \\
\text { the last line (efficiency) }\end{array}$ & $0.64 \pm 0.44$ & $0.53 \pm 0.39$ & 0.606 & \\
\hline & Make a tackle to the rival (efficiency) & $0.31 \pm 0.32$ & $0.65 \pm 0.35$ & 0.068 & \\
\hline & Intercept, clear or divert a pass (efficiency) & $0.81 \pm 0.37$ & $0.58 \pm 0.50$ & 0.314 & \\
\hline & Block a shot (efficiency) & $0.16 \pm 0.23$ & $0.00 \pm 0.00$ & 0.074 & \\
\hline & Redirect the opponent's attack (efficiency) & $0.75 \pm 0.13$ & $0.43 \pm 0.23$ & $0.004 *$ & 1.71 \\
\hline & $\begin{array}{l}\text { Do not give the opponent a shot option without } \\
\text { entering him (avoid possible shot) (efficiency) }\end{array}$ & $0.10 \pm 0.20$ & $0.37 \pm 0.26$ & $0.041 *$ & \multirow[t]{2}{*}{-1.16} \\
\hline & $\begin{array}{l}\text { Take care of the partner's back in the intervention } \\
\text { space in a staggered manner (efficiency) }\end{array}$ & $0.87 \pm 0.12$ & $0.66 \pm 0.31$ & 0.089 & \\
\hline & $\begin{array}{l}\text { Move to create superiority in the game center or } \\
\text { mark/watch opponents (efficiency) }\end{array}$ & $0.96 \pm 0.06$ & $0.63 \pm 0.34$ & $0.019 *$ & 1.241 \\
\hline & $\begin{array}{l}\text { Create uncertainty in the last opponent line or } \\
\text { reduce the effective playing space (efficiency) }\end{array}$ & $0.83 \pm 0.36$ & $0.40 \pm 0.43$ & $0.043 *$ & 1.08 \\
\hline & $\begin{array}{l}\text { Relocation in the last defensive line reducing the } \\
\text { effective playing space (efficiency) }\end{array}$ & $0.97 \pm 0.05$ & $0.34 \pm 0.38$ & 0 * & \multirow[t]{2}{*}{2.32} \\
\hline & $\begin{array}{l}\text { Increase the protection of the goal, marking or } \\
\text { watching opponents (efficiency) }\end{array}$ & $0.77 \pm 0.34$ & $0.61 \pm 0.33$ & 0.349 & \\
\hline \multirow{3}{*}{$\begin{array}{l}\text { Overall } \\
\text { scores }\end{array}$} & Total Average & $8.11 \pm 0.67$ & $6.43 \pm 0.86$ & $0.001 *$ & 2.18 \\
\hline & Offensive Average & $9.01 \pm 0.68$ & $7.38 \pm 1.08$ & $0.003 *$ & 1.81 \\
\hline & Defensive Average & $7.20 \pm 0.86$ & $5.48 \pm 1.58$ & $0.017^{*}$ & 1.35 \\
\hline
\end{tabular}

Semi-professional football players $(n=8)$; amateur football players $(n=8) ;(*)$ except in the rival field; $(* *)$ average of general tactical behaviors $\times 10$. 


\subsection{Intra-Observer Reliability}

To calculate the intra-observer stability index, test-retest reliability was used by applying Cohen's kappa to the data extracted from the observation of a player with a difference of five weeks between both records. In relation to the records made, it should be clarified that some error of omission in the record of any category may cause a mismatch between records, causing a possible underestimation of the concordance coefficient [63]. To avoid this, and before proceeding to calculate the Cohen's kappa index, a filter was developed manually, matching those identifiable behaviors through their temporal registration. Once this process had been carried out, the results showed an agreement index of 0.747 , which could be valued as good [64] regarding an observational tool with these characteristics.

\subsection{Inter-Observer Reliability}

The inter-observer reliability of FOCOS was calculated following the same manual filtering process that was used in the intra-observer reliability calculation. To calculate the inter-observer concordance coefficient for more than two observers $(n=3)$, Fleiss kappa was applied. The values obtained $(\mathrm{k}=0.766)$ showed a good agreement.

\subsection{Generalizability Analysis}

The generalizability analysis was carried out in the SAGT v1.0 build 218.0.1 software program [65], using two possible models: Categories/Observers and Observers/Categories (see Table 6).

Table 6. Estimated values of the relative coefficients $\left(\xi \rho^{2}{ }_{(\delta)}\right)$ and absolute $\left(\xi \rho^{2}{ }_{(\Delta)}\right)$ of generalizability for the designs Categories:Observers [C:O] and Observers:Categories [O:C].

\begin{tabular}{cccccc}
\hline & $\begin{array}{c}\text { Sum Squares } \\
\text { Type III }\end{array}$ & $\begin{array}{c}\text { Degrees of } \\
\text { Freedom }\end{array}$ & $\begin{array}{c}\text { Mean } \\
\text { Squares }\end{array}$ & $\begin{array}{c}\text { Standard } \\
\text { Error }\end{array}$ & $\%$ \\
\hline Observers [O] & 0.0 & 2 & 0.000 & 0.010 & 0 \\
\hline Categories [C] & $11,389.1$ & 34 & 334.972 & 26.318 & 100 \\
CO & 144.7 & 68 & 2.127 & 0.360 & 0 \\
\hline \multirow{2}{*}{ Designs } & {$[\mathrm{C}: \mathrm{O}]$} & & $\xi \rho^{2}(\delta)=0.994 \mathrm{y} \xi \rho^{2}(\Delta)=0.994$ & \\
& {$[\mathrm{O}: \mathrm{C}]$} & & $\xi \rho^{2}{ }_{(\delta)}=0.001 \mathrm{y} \xi \rho^{2}(\Delta)=0.001$ & \\
\hline
\end{tabular}

The [C:O] design was used to calculate the inter-observer reliability. The relative generalizability coefficient is associated with high reliability in the generalization precision of the results (close to 1). To assess construct validity, the [O:C] design was used. The generalizability coefficients were found to be close to 0 (for both coefficients, relative and absolute). The possible sources of variance showed that most of the variability $(100 \%)$ was associated with the categories facet, being null in the rest of the facets: Observers $(0 \%)$, and Observers:Categories ( $0 \%)$. This reveals that the established categories are heterogeneous and, therefore, exclusive within the configured taxonomic system.

\section{Discussion}

The aim of the present study is to describe the steps carried out to design and assess the validity and reliability of a new proposal of an ad-hoc observational tool. The developed instrument allows us to analyze and evaluate the player's PTK, both in attack and defense, unlike other tools such as GPET [21] and KORA [18] which focus only on the offensive phase, or TSAP [16] which exclusively analyzes the player when he has the ball.

Based on the record of the motor behaviors developed by the player, FOCOS allows evaluating their performance based on several criteria: the roles, the own actions of the acquired subroles, the operational principles and the specific principles. In this sense, the complete analysis of the behaviors that the player can develop during his performance is another advantage of FOCOS compared to other tools. FUT-SAT [20] does not evaluate the behaviors displayed by the player, and although TSAP [16], GPAI [17], KORA [18], 
GPET [21] and IMLPFoot [22] evaluate certain behaviors, they do not cover all the possibilities that the player has to respond to any game-play situation. Furthermore, the use of sociomotor roles and subroles to classify tactical behaviors is another contribution of the tool, allowing a more rigorous analysis. In addition, the evaluation of both operating principles and specific principles represents a great advantage over other tools such as FUT-SAT [20] which is focused only on specific principles, GPET [21] which analyzes operational principles, or TSAP [16], GPAI [17], KORA [18] and IMLPFoot [22] which are not articulated around game principles.

Another advantage of the tool is its protocol because it has a sustainable and easily applicable game format. FOCOS uses a SSG Gk $+4 v 4+$ GK in football double area (for U13 players or older) or half football field-7 (for U12 players). Regarding this fact, different game formats are used in other tools: 3v3 without goals in KORA [18], Gk + 3v3 + Gk in FUT-SAT [20] and IMLPFoot [22]; Gk + 5v5 + Gk in GPAI [17], and from 2v2 to 7v7, in GPET [21] according to the age of the players. The use of SSGs that guarantee the representativeness [66] of the football game seems to be something on which most of the authors agree. In this study, Gk $+4 \mathrm{v} 4+\mathrm{Gk}$ has been used because it is a game format that facilitates the occupation of the entire space in depth and width. Spaces of greater width than length have been used, since the interaction contexts [63] generated by the teams during a match usually have this characteristic, and the SSGs have the particularity of facilitating that all the players participate actively due to their proximity to the game center.

For everything mentioned, it is understood that the knowledge of the strengths and weaknesses of each player by the coach or coaching staff can be used to optimize the teaching-training processes from the subroles (divergent learning) or principles (convergent learning). The subroles represent, in one way or another, the most applicable version of the player's technique in the tactical context that is presented, and they are related to exploratory capacity, while the principles are closely linked to learning a set of action rules common to any game model within the tactical framework that presents football as a sociomotor sport.

Respecting the applicability of the instrument, several possibilities can be found: (1) within a team, the player's football competence could be periodically analyzed, allowing to evaluate his evolution compared to himself and his teammates; (2) also, the level of football competence of new players who train with a team on a trial basis could be assessed; (3) in recruitment days, those players who show an adequate level of football competence in the eyes of coaches and scouts could be evaluated in detail, in order to identify possible sports talents; (4) could also be used to complement the analysis performed using positional data tools. Considering this fact, the positional data focuses on the team, analyzing variables such as team length, team width and team surface area [67], while FOCOS is focused on the player, analyzing aspects already mentioned that are conceptually closer to those managed by coaches.

Regarding the limitations of this study, it can be noted that it was decided not to calculate the criterion validity of the tool, understood as concurrent or concomitant validity; that is, the degree of correlation between two measures of the same concept, at the same time and in the same subjects [68]. For this, FOCOS would have to be compared with an external criterion that intended to measure the same, but there are no tools in the scientific literature with the level of depth that FOCOS presents. This level of complexity implies several limitations: the deep knowledge of the tool and the game to be able to use it, the large volume of information that is handled, the temporary and human resources for its use on a large scale, as well the impossibility of applying it in real time.

\section{Conclusions}

As conclusions of the study, it should be mentioned that the coding instrument presented shows optimal validity and reliability values. It is the first instrument collected in the scientific literature, which is structured interactively based on the roles, the actions of the subroles, the operational principles and the specific principles of the game of football. 
It can fully analyze, both in attack and defense phases, the player's procedural tactical knowledge, understood as football competence. It is able to analyze and evaluate the player in detail from a technical-tactical point of view, based on the motor behaviors that he performs using the subroles that he acquired, associated with the technical, and the principles that he develops in parallel, in support of the tactical dimension. This aspect represents something pioneering within the range of observational instruments directed towards the analysis of the player's PTK. Based on these conclusions, the instrument could be used for scientific purposes to carry out possible research projects or specific studies, as well as by clubs, performance analysis departments and coaches to analyze and evaluate their players in detail, and thus improve their teaching and training processes.

Author Contributions: Conceptualization, R.S.-L., I.E. and J.C.; methodology, R.S.-L., I.E. and J.C.; validation, R.S.-L.; formal analysis, R.S.-L., I.E. and J.C.; investigation, R.S.-L.; data curation, R.S.L.; writing-original draft preparation, R.S.-L.; writing-review and editing, R.S.-L., I.E. and J.C.; visualization, R.S.-L.; supervision, I.E. and J.C.; funding acquisition, J.C. All authors have read and agreed to the published version of the manuscript.

Funding: The authors gratefully acknowledge the support of a Spanish government subproject Mixed method approach on performance analysis (in training and competition) in elite and academy sport [PGC2018-098742-B-C33] (2019-2021) [del Ministerio de Ciencia, Innovación y Universidades (MCIU), la Agencia Estatal de Investigación (AEI) y el Fondo Europeo de Desarrollo Regional (FEDER)], that is part of the coordinated project New approach of research in physical activity and sport from mixed methods perspective (NARPAS_MM) [SPGC201800X098742CV0].

Institutional Review Board Statement: The study was conducted according to the guidelines of the Declaration of Helsinki and Organic Law 15/1999 of 13th December on the protection of personal data (BOE, 298, 14th December 1999) in order to guarantee the ethical considerations of scientific research with human subjects. Ethical approval was waived for this study because no invasive measures were performed to obtain the data.

Informed Consent Statement: Informed consent was obtained from all subjects involved in the study.

Data Availability Statement: Not applicable.

Conflicts of Interest: The authors declare no conflict of interest.

\section{References}

1. Parlebas, P. Elementos de Sociología Del Deporte; Unisport Andalucía: Málaga, Spain, 1988.

2. Teoldo, I.; Guilherme, J.; Garganta, J. Training Football for Smart Playing: On Tactical Performance of Teams and Players; Appris: Curitiba, Brazil, 2015; p. 319.

3. Thomas, J.R.; French, K.E.; Humphries, C.A. Knowledge Development and Sport Skill Performance: Directions for Motor Behavior Research. J. Sport Psychol. 1986, 8, 259-272. [CrossRef]

4. Kirkhart, M.W. The Nature of Declarative and Nondeclarative Knowledge for Implicit and Explicit Learning. J. Gen. Psychol. 2001, 128, 447-461. [CrossRef]

5. Teoldo, I.; Garganta, J.; Greco, P.J.; Mesquita, I. Proposta de Avaliação Do Comportamento Tático de Jogadores de Futebol Baseada Em Princípios Fundamentais Do Jogo. Mot. Rev. Educ. Física 2011, 17, 511-524. [CrossRef]

6. Williams, M.; Davids, K. Declarative Knowledge in Sport: A by-Product of Experience or a Characteristic of Expertise? J. Sport Exerc. Psychol. 1995, 17, 259-275. [CrossRef]

7. Garganta, J. Modelação Táctica Do Jogo de Futebol: Estudo Da Organização Da Fase Ofensiva Em Equipas de Alto Rendimento; University of Porto: Porto, Portugal, 1997.

8. French, K.E.; Thomas, J.R. The Relation of Knowledge Development to Children's Basketball Performance. J. Sport Psychol. 1987, 9, 15-32. [CrossRef]

9. Parlebas, P. Une Pédagogie Des Compétences Motrices. Acción Motriz. 2018, 20, 89-96.

10. Sarmento, H.; Marcelino, R.; Anguera, M.T.; CampaniÇo, J.; Matos, N.; LeitÃo, J.C. Match Analysis in Football: A Systematic Review. J. Sports Sci. 2014, 32. [CrossRef]

11. Ferrari, W.R.; Sarmento, H.; Vaz, V. Match Analysis in Handball: A Systematic Review. Montenegrin J. Sports Sci. Med. 2019, 8 , 63-76. [CrossRef]

12. Agras, H.; Ferragut, C.; Abraldes, J.A. Match Analysis in Futsal: A Systematic Review. Int. J. Perform. Anal. Sport. 2016, 16, 652-686. [CrossRef] 
13. Silva, M.; Marcelino, R.; Lacerda, D.; João, P.V. Match Analysis in Volleyball: A Systematic Review. Montenegrin J. Sports Sci. Med. 2016, 5, 35-46.

14. Courel-Ibáñez, J.; McRobert, A.P.; Toro, E.O.; Vélez, D.C. Collective Behaviour in Basketball: A Systematic Review. Int. J. Perform. Anal. Sport 2017, 17, 44-64. [CrossRef]

15. Anguera, M.T. Metodología de La Observación En Las Las Ciencias Humanas; Catedra: Madrid, Spain, 1992.

16. Gréhaigne, J.-F.; Godbout, P.; Bouthier, D. Performance Assessment in Team Sports. J. Teach. Phys. Educ. 1997, 16, 500-516. [CrossRef]

17. Oslin, J.L.; Mitchell, S.A.; Griffin, L.L. The Game Performance Assessment Instrument (GPAI): Development and Preliminary Validation. J. Teach. Phys. Educ. 1998, 17, 231-243. [CrossRef]

18. Kröger, C.; Roth, K. Escola Da Bola: Um ABC Para Iniciantes Nos Jogos Esportivos [School Ball: An ABC Sports Games for Beginners]; Phorte: Sao Paulo, Brazil, 2002.

19. Memmert, D. Diagnostik Taktischer Leistungskomponenten: Spieltestsituationen Und Konzeptorientierte Expertenratings [Tactical Performance Components Valuation: Test Situations and Concept-Oriented Expert Ratings]. Ph.D. Thesis, Heidelberg University, Heidelberg, Germany, 2002.

20. Teoldo, I.; Garganta, J.; Greco, P.J.; Mesquita, I.; Maia, J. Sistema de Avaliação Táctica No Futebol (FUT-SAT): Desenvolvimento e Validação Preliminar. /System of Tactical Assessment in Soccer (FUT-SAT): Development and Preliminary Validation. Motricidade 2011, 7, 69-84.

21. García-López, L.M.; González-Víllora, S.; Gutiérrez-Díaz, D.; Serra-Olivares, J. Development and Validation of the Game Performance Evaluation Tool (GPET) in Soccer. Sport Rev. Euroam. Cienc. Deporte 2013. [CrossRef]

22. García-Ceberino, J.M.; Antúnez, A.; Ibáñez, S.J.; Feu, S. Design and Validation of the Instrument for the Measurement of Learning and Performance in Football. Int. J. Environ. Res. Public Health. 2020, 17, 4629. [CrossRef]

23. González-Víllora, S.; Serra-Olivares, J.; Pastor-Vicedo, J.C.; Teoldo, I. Review of the Tactical Evaluation Tools for Youth Players, Assessing the Tactics in Team Sports: Football. SpringerPlus 2015, 4, 663. [CrossRef]

24. Dugas, E. L'avaluació de Les Conductes Motrius En Els Jocs Col- Lectius: Presentació d'un Instrument Científic Aplicat a l'educació Física. Apunt. Educ. Física Deportes. 2006, 1, 61-69.

25. Hernández Moreno, J. Análisis de Las Estructuras Del Juego Deportivo; INDE: Barcelona, Spain, 1994.

26. Castelo, J. Futebol. Modelo Técnico-Táctico Do Jogo; Edições FMH: Lisboa, Portugal, 1994.

27. Lago, C. La Acción Motriz En Los Deportes de Equipo de Espacio Común y Participación Simultánea. Ph.D. Thesis, Universidad de A Coruña, Galicia, Spain, 2000.

28. Obœuf, A.; Collard, L.; Pruvost, A.; Lech, A. La Prévisibilité Au Service de l'impré Visibilité. À La Recherche Du «code Secret» Du Football. Reseaux 2009, 156, 241-270. [CrossRef]

29. Marqués, D.; de Santos, R.M.; Gorostiaga, D.S. Data Quality Control of an Observational Tool to Analyze Football Semiotricity. Cuad. Psicol. Deport. 2015, 15, 223-232. [CrossRef]

30. Lasierra, G. Análisis de La Interacción Motriz En Los Deportes de Equipo. Aplicación de Los Universales Ludomotores Al Balonmano. Apunt. Educ. Física Deportes. 1993, 32, 37-53.

31. Bayer, C. L'ensegnement Des. Jeux Sportifs Collectifs; Vigot. Edc: Paris, France, 1979.

32. Queiroz, O. Para Uma Teoria Do Ensino/ Treino Do Futebol. Futeb. em Rev. 1983, 4, 47-49.

33. Garganta, J.; Pinto, J. O Ensino Do Futebol. In O Ensino dos Jogos Desportivos; Oliveira, A., Graça, J., Eds.; Faculdade de Ciências do Desporto e de Educação Física da Universidade do Porto: Porto, Portugal, 1994; pp. 95-136.

34. Castelo, J. Futebol-a Organização Do Jogo. In Estudos 2-Estudo dos Jogos Desportivos. Concepções, Metodologias e Instrumentos; Tavares, F., Ed.; Faculdade de Desporto da Universidade do Porto: Porto, Portugal, 1999; pp. 41-49.

35. Hainaut, K.; Benoit, J. Enseignement Despratiques Physiques Spécifiques: Le Football Moderne-Tactique-Technique-Lois Du Jeu; Presses Universitaires de Bruxelles: Brussel, Belgium, 1979.

36. Teoldo, I.; Garganta, J.; Greco, P.J.; Mesquita, I. Princípios Táticos Do Jogo de Futebol: Conceitos e Aplicação. Mot. Rio Claro. 2009, 15, 657-668.

37. Worthington, E. Learning E Teaching Soccer Skills; Publ. Melvin Powers, Wilshire Book Company: Chatsworth, CA, USA, 1974.

38. Praça, G.M.; Pérez-Morales, J.C.; Moreira, P.E.D.; Peixoto, G.H.C.; Bredt, S.T.; Chagas, M.H.; Teoldo, I.; Greco, P.J. Tactical Behavior in Soccer Small-Sided Games: Influence of Team Composition Criteria. Braz. J. Kinanthropometry Hum. Perform. 2017, 19, 354. [CrossRef]

39. Teoldo, I.; Garganta, J.; Greco, P.J.; Mesquita, I. Análise e Avaliação Do Comportamento Tático No Futebol. Rev. Educ. Fis. 2010, 21, 443-455.

40. Tenga, A.; Kanstad, D.; Ronglan, L.T.; Bahr, R. Developing a New Method for Team Match Performance Analysis in Professional Soccer and Testing Its Reliability. Int. J. Perform. Anal. Sport 2009, 9, 8-25. [CrossRef]

41. Cronbach, L.J.; Meehl, P.E. Construct Validity in Psychological Tests. Psychol. Bull. 1955, 52, 281-302. [CrossRef]

42. Anguera, M.T.; Blanco-Villaseñor, Á.; Hernández-Mendo, A.; Losada, J.L. Diseños Observacionales: Ajuste y Aplicación En Psicología Del Deporte. Cuad. Psicol. Deport. 2011, 11, 63-76.

43. Anguera, M.T.; Blanco-Villaseñor, Á. Cómo Se Lleva a Cabo Un Registro Observacional? Butilletí Lar. 2006, 4, 1-7.

44. Bakeman, R. Untangling Streams of Behavior: Sequential Analysis of Observation Data. In Observing Behavior: Vol. 2. Data Collection and Analysis Methods; Sackett, G.P., Ed.; University of Park Press: Baltimore, MD, USA, 1978; pp. 63-78. 
45. Caicedo Parada, S.A.; Calderón Vargas, M.A. Diseño y Validación de Un Instrumento Observacional Para La Valoración de Acciones Tácticas Ofensivas En Fútbol-Vatof (Design and Validation of an Observational Instrument for the Evaluation of Offensive Tactical Actions in Football-Vatof). Retos 2020, 38, 306-311. [CrossRef]

46. Aranda, R.; González-Ródenas, J.; López-Bondia, I.; Aranda-Malavés, R.; Tudela-Desantes, A.; Anguera, M.T. “REOFUT” as an Observation Tool for Tactical Analysis on Offensive Performance in Soccer: Mixed Method Perspective. Front. Psychol. 2019, 10, 1476. [CrossRef] [PubMed]

47. Chacón-Moscoso, S.; Anguera, M.T.; Sanduvete-Chaves, S.; Losada, J.L.; Lozano-Lozano, J.A.; Portell, M. Methodological Quality Checklist for Studies Based on Observational Methodology (MQCOM). Psicothema 2019, 31. [CrossRef]

48. Gabin, B.; Camerino, O.; Anguera, M.T.; Castañer, M. Lince: Multiplatform Sport Analysis Software. Procedia Soc. Behav. Sci. 2012, 46, 4692-4694. [CrossRef]

49. Casamichana, D.; Castellano, J. Time-Motion, Heart Rate, Perceptual and Motor Behaviour Demands in Small-Sides Soccer Games: Effects of Pitch Size. J. Sports Sci. 2010, 28, 1615-1623. [CrossRef]

50. Hernández Nieto, H. Contributions to Statistical Analysis; Universidad de los Andes: Mérida, Venezuela, 2002.

51. Bulger, S.M.; Housner, L.D. Modified Delphi Investigation of Exercise Science in Physical Education Teacher Education. J. Teach. Phys. Educ. 2007, 26, 57-80. [CrossRef]

52. Soto, A.; Camerino, O.; Iglesias, X.; Anguera, M.T.; Castañer, M. LINCE PLUS: Research Software for Behavior Video Analysis. Apunt. Educ. Física Esports 2019, 149-153. [CrossRef]

53. Fernandes, T.; Camerino, O.; Garganta, J.; Pereira, R.; Barreira, D. Design and Validation of an Observational Instrument for Defence in Soccer Based on the Dynamical Systems Theory. Int. J. Sport. Sci. Coach. 2019, 14, 138-152. [CrossRef]

54. Barreira, D.; Garganta, J.; Prudente, J.; Anguera, M.T. Desenvolvimento e Validacão de Um Sistema de Observacação Aplicado à Fase Ofensiva Em Futebol: SoccerEye. Rev. Port. Cien Desp. 2012, 12, 32-57.

55. Ortega-Toro, E.; García-Angulo, A.; Giménez-Egido, J.M.; García-Angulo, F.J.; Palao, J.M. Design, Validation, and Reliability of an Observation Instrument for Technical and Tactical Actions of the Offense Phase in Soccer. Front. Psychol. 2019, 10, 22. [CrossRef]

56. Echeazarra, I. Análisis de La Respuesta Física y Del Comportamiento Motor En Competición de Futbolistas de Categoría Alevín, Infantil y Cadete, Tesis Doctoral; Universidad del País Vasco: Leioa, Biscay, Spain, 2014.

57. Cronbach, L.J.; Gleser, G.C.; Nanda, H.; Rajaratnam, N. The Dependability of Behavioral Measurements: Theory of Generalizability for Scores and Profiles; Sons, J.W., Ed.; Wiley: New York, NY, USA, 1972.

58. McDowell, I.; Newell, C. Measuring Healh: A Guide to Rating Scales and Questionnaires; Oxford University Press: New York, NY, USA, 1996.

59. Castellano, J.; Hernández-Mendo, A.; Gómez De Segura, P.; Fontetxa, E.; Bueno, I. Sistema de Codificación y Análisis de La Calidad Del Dato En El Fútbol de Rendimiento. Psicothema 2000, 12, 635-641.

60. Anguera, M.T. Metodología Observacional. In Metodología de la Investigación en Ciencias del Comportamiento; Arnau, J., Anguera, M.T., Benito, J.G., Eds.; Universidad de Murcia: Murcia, Spain, 1990; pp. 125-238.

61. Cohen, J. Statistical Power Analysis for the Behavioural Sciences; Lawrence Earlbaum Associates: Mahwah, NJ, USA, 1988.

62. Hopkins, W.G.; Marshall, S.W.; Batterham, A.M.; Hanin, J. Progressive Statistics for Studies in Sports Medicine and Exercise Science. Med. Sci. Sports Exerc. 2009, 41, 3-12. [CrossRef]

63. Castellano, J. Observación y Análisis de Juego En El Fútbol. Ph.D. Thesis, Universidad del País Vasco, Leioa, Biscay, Spain, 2000.

64. Altman, D. Practical Statistics for Medical Research; Chapman and Hall: London, UK, 1991.

65. Hernández-Mendo, A.; Blanco-Villaseñor, Á.; Pastrana, J.L.; Morales-Sánchez, V.; Ramos-Pérez, F.J. SAGT: New Software for Generalizability Analysis. Rev. Iberoam. Psicol. Ejerc. Deport. 2016, 11, 77-89.

66. Bunker, D.; Thorpe, R. A Model for the Teaching of Games in Secondary Schools. Bull. Phys. Educ. 1982, 18, 5-8.

67. Olthof, S.B.H.; Frencken, W.G.P.; Lemmink, K.A.P.M. A Match-Derived Relative Pitch Area Facilitates the Tactical Representativeness of Small-Sided Games for the Official Soccer Match. J. Strength Cond. Res. 2019, 33. [CrossRef]

68. Polit, D.; Hungler, B. Nursing Research: Principles and Methods; JB Lippincott \& Co: Philadelphia, PA, USA, 1999. 